\title{
СИНТАКСИЧНА СТРУКТУРА ІМПЕРАТИВІВ ТА ОСОБЛИВОСТІ ЇХ ВЖИВАННЯ В ІСТОРІї АНГЛІЙСЬКОЇ МОВИ
}

\author{
Зізінська А. П.
}

\section{ВСТУП}

Дослідження директивних мовленнєвих актів в історії англійської мови порушує низку питань і проблем, які неможливо охопити суто синхронічним аналізом. Натепер мовленнєві акти прохання, наказів тощо розглядаються науковцями як приклади актів «загрози обличчю» (face-threatening acts). У соціумі та під час комунікації їх часто вважають загрозою «негативного обличчя» (negative face) адресата, тобто втручання у свободу дій та нав'язування, що загрожує бажанню комуніканта бути незалежним ${ }^{1}$. Керуючись цією інформацією, можна легко пояснити велику кількість так званих непрямих директивів (indirect directives) у сучасній англійській мові (наприклад, Could you help me? Will you open the window?). Нещодавні розвідки показують, що багато непрямих директивних мовленнєвих актів з'явились в історії англійської мови в досить пізній період. Наприклад, чіткі випадки директивів у вигляді запитань важко знайти до початку ранньоновоанглійського періоду. Те ж стосується й інших непрямих директивів ${ }^{2}$. Однак більш очевидні та прямі прояви директивів, які сьогодні вважалися б недоречними та неввічливими, були досить поширеними та часто вживались у рані періоди англійської мови. Звідси постає питання про норми мовленнєвих актів і рівень лінгвістичної ввічливості в період минулих століть.

Одним із завдань сучасної теорії синтаксису $\epsilon$ дослідження структури речення. Дослідників цікавить процес і способи побудови речень у синхронному та діахронному аспектах.

У сучасній лінгвістиці актуальними залишаються питання, що стосуються функціональних і структурних особливостей імператива. Імперативи в генеративній парадигмі досліджували такі вчені, як: Дж.

1 Brown P., Levinson S. Politeness: Some Universals in Language Usage. Cambridge : Cambridge University Press, 1987.

${ }^{2}$ Kohnen Thomas. "Let mee bee so bold to request you to tell me": Constructions with "let me" in the history of English directives. Journal of Historical Pragmatics. 2004. № 5:1. P. 159-173. 
Садок та А. Звіцкі (1985 р.), В. ван дер Вурфф (2007 р.), Е. Потсдам (1998р.), Дж. Лайонс і Р. Хаддлстон (1977 р.), Ч. Хан (2000р.), К. Плацак (1998 р.), Л. Рупп (1999 р.), Е. Девіс (1986 р.) та ін.

Об'єктом нашого дослідження $\epsilon$ імперативи в середньоанглійському та ранньоновоанглійському періодах (XII - XVII ст.), предметом є їхні структурні особливості. Актуальність дослідження зумовлена сучасними напрямами вивчення лінгвістичних студій, спрямованих на вивчення структури речення. Мета дослідження полягає у визначенні структурних особливостей і засобів вираження імперативів у діахронічному аспекті.

Дослідження мовленнєвих актів (далі - МА) у діахронії стикається 3 деякими труднощами. Головними проблемами $є$ неможливість охопити весь обсяг матеріалу з реалізацією мовленнєвих актів в історії мови, а також складність їх диференціації, оскільки поведінка та розвиток в історії мови можуть змінюватись. Наприклад, під час дослідження директивів, а саме імперативів, неможливо знати всі способи їх реалізації протягом усіх періодів в історії англійської мови. Тому дослідникам доводиться робити еклетичний аналіз «типових» форм вираження, які, на їхню думку, найчастіше спостерігаються в історичному корпусі. Застосування електронних корпусів у дослідженні мовленнєвих актів є проблематичним, оскільки цей аналіз базується на формі, що робить неможливим систематично чи автоматично виділити мовленнєвий акт. Тому, на нашу думку, метод суцільної вибірки є найбільш надійним для такого виду дослідження, хоча і потребує багато часу для обробки матеріалу. Тому вченим доводиться шукати альтернативні способи для розвідок. І. Тавітсенн $\mathrm{i}$ А. Джукер ${ }^{3}$ розглядають директив через дієслово-маркер. Таким чином полегшується робота 3 ïх пошуком у корпусі. За допомогою цього підходу можна дослідити всі літературні пам'ятки, наявні в корпусі, та отримати чітку картину про використання відповідних мовленнєвих актів. Але в цьому підході є теж недоліки, оскільки він не дає змогу дослідити всі способи реалізації директивів в історичному корпусі. У нашому дослідженні застосовано метод суцільної вибірки, що дозволило нам грунтовно проаналізувати досліджувані одиниці. Матеріалом нашої розвідки слугують пам'ятки ранньоновоанглійської писемності.

${ }^{3}$ Taavitsainen Irma, Jucker Andreas. Speech acts verbs and speech acts in the history of English. Methods in Historical Pragmatics / Irma Taavitsainen, Susan Fitzmaurice (eds.). Berlin ; New York : Mouton de Gruyter, 2007. P. 107-138. 


\section{1. Класифікація імперативів у середньоанглійський і ранньоновоанглійський періоди}

Визначаючи імператив як окремий синтаксичний клас, необхідно відділяти функції від структури, розглядаючи елементи останньої як незалежні, структурні (синтаксичні) особливості типу клаузи. Так, наприклад, імперативи зазвичай уживаються як накази, а декларативи як ствердження. У нашому дослідженні ми будемо аналізувати імперативи як «імперативну клаузу» (клауза 3 імперативними синтаксичними ознаками), виділяючи водночас «дієслово-імператив».

Як зазначають Р. Браун і А. Гілман ${ }^{4}$, численні дослідження присвячені середньоанглійським імперативам, але все ж головною проблемою залишається відокремлення граматичного імператива від директивних. Як у середньоанглійській, так і в сучасній мові директиви часто виражались за допомогою імперативних конструкцій.

У результаті нашого дослідження нам вдалося виділити та проілюструвати такі структури імперативів у середньоанглійській i ранньоновоанглійській мовах:

1) імператив у вигляді основного дієслова. Напр.: Wende! Go!

Такий тип імператива складається з одного смислового дієслова в наказовому способі та матиме таку схему [V]:

2) $\boldsymbol{L e t}+$ особовий займенник + смислове дієслово $(\boldsymbol{L e t}+$ personal pronoun + verb):

(1) "Let him us alle knighte / For that is urerighte!" (King Horn, 519) "Нехай він нас посвятить у лииарі / Тому що ми маємо на ие право!»;

(2) "Let me ligge and go the weihenne!" (Bevis of Hampton, 1185) «Залиш мене тут і йди своїм иляхом!».

Let належить до маркерів увічливості, тому вживання його в реченні надає ознак прохання імперативу.;

3) Смислове дієслово + займенник thee / the / thou / уои (Verb + $2^{\text {nd }}$ person pronoun):

(3) "Reste thee $<\ldots>$ " (Bevis of Hampton, 1006) - «Вiдnочинь $<\ldots>$ »;

(4) "Bithenke the of thi michel honour" (Amis and Amiloun, 595) «Пам'ятай про велику честь»;

(5) “< ..> wende thou hom with me” (Stanziac Guy of Warwick, 2928) «<..> ходи зі мною додому»;

4) звертання + смислове дієслово в наказовому способі (Form of address + verb):

(6) “Knight, awake! / Seie what thukepest?"(King Horn, 1320) «Прокинься, лицарю! / Скажи, щчо ти охороняєш?»;

4 Brown R., Gilman A. Polite theory and Shakespeare's four major tragedies. Language in Society. 1989. № 18. P. 159-212. 
(7) "King, - he sede, - thu leste / A tale mid the beste" (King Horn, 1275) - «Королю, - він сказав, - послухай / Розповідь одну 3 найкраших";

(8) "Sir emperor, - he seyd, - listen to me" (Stanziac Guy of Warwick, 2446) - «Iмпереторе, - він сказав, - послухай мене»;

5) дієслово pray/preie + займенник 2-ої особи (pray / preie + $2^{\text {nd }}$ person pronoun):

(9) "For Godes love Y pray you / Gode conseyl give me now" (Stanziac Guy of Warwick, 2854-2855) - «В ім'я Богів я тебе прошу / Дати мені гарну пораду»;

(10) "I pray thee, lady, the moder of Crist, / Praieth youre sone me to spare” (Mary Mediatrix, 54, 1-2) - «Я прошу тебе, діво, мати Христа, / Молись своєму синові, щзоб він мене помилував».

$\mathrm{y}$ середньоанглійській мові часто дієслово pray уживалось у значенні «просити», додаючи до імператива властивостей прохання. Це дієслово засвідчено із займенником другої особи, розміщеним пре/постпозитивно;

6) Do + verb:

(11) "Do bringe that child before thee!" (Bevis of Hampton, 663) «Приведи ию дитину!».

Допоміжне дієслово $d o$ в поєднанні зі смисловим дієсловом уживалось у наказах, акцентуючи водночас увагу на серйозності виконання дії.

Імперативи спонукають адресата (не)зробити щось після моменту мовлення. Імперативні речення зазвичай не мають підмета i складаються зі смислового дієслова або допоміжного дієслова в поєднанні зі смисловим. У середньоанглійській мові в імперативних структурах підмета також здебільшого не було або він ішов після смисловго дієслова.

У результаті нашого дослідження ми виявили, що імперативи, після яких слідує займенник другої особи, як-от Go уоu, Wende thee, Take thou, є більш увічливими, ніж просто накази.

\section{2. Особливості синтаксичної структури імперативів у діахронії}

У сучасній англійській мові основними комунікативними типами речень $\epsilon$ розповідне, питальне, наказове й окличне. Наказові речення визначаються морфосинтаксичними, семантичними або прагматичними особливостями.

Оскільки наказове речення виражає спонукальну дію, то основною структурною особливістю його $\epsilon$ те, що підмет цього речення $\epsilon$ семантично передбаченим, а отже, необов'язковим. Заперечні наказові 
речення утворюються за допомогою допоміжного дієслова $d o$, яке слугує наказовим маркером: Don't go there!

Синтаксичні особливості імперативів тривалий час були питанням для дискусій серед дослідників генеративної граматики (Г. Колшанський, І. Ревзін, 3. Харріс, Н. Хомський). Імперативи в досліджуваний період уживались для реалізації директивів.

Імперативні конструкції в ранньоновоанглійський період, як і в попередній середньоанглійський, були більш гнучкими, ніж у сучасній англійській мові, оскільки порядок слів у досліджуваний період залишався менш фіксованим.

3 розвитком генеративної граматики, а саме Ікс-штрих-теорії, трактування та підходи до структури і позиційних особливостей імперативів зазнали змін. Модель (1) дозволяє дослідити позиційне розташування конституентів i порядок слів у реченні. Отже, дериваційна структура імператива розглядається так:

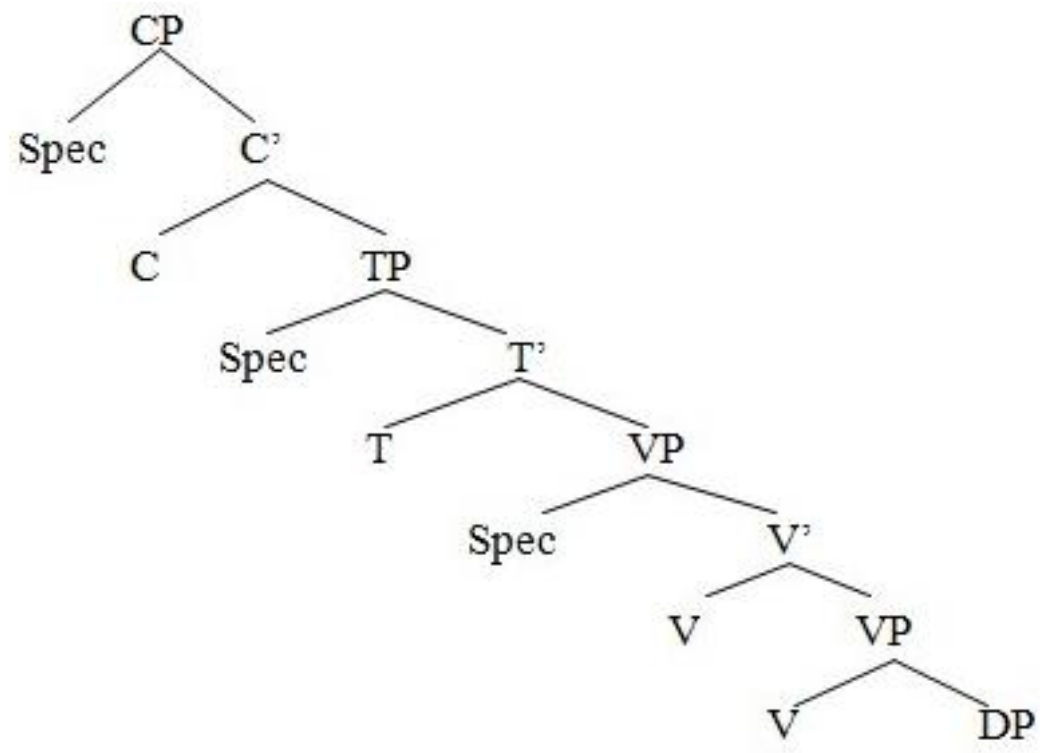

Модель 1. Структура імперативної клаузи

У сучасній англійській мові згідно з Ікс-штрих-теорією у структурі імператива відбувається пересув. Таким чином $V$ переходить у $T$, а $T$, у свою чергу, у $C$ :

$\mathrm{V} \mathrm{T}$;

T C. 
Структурно це можна проілюструвати так:

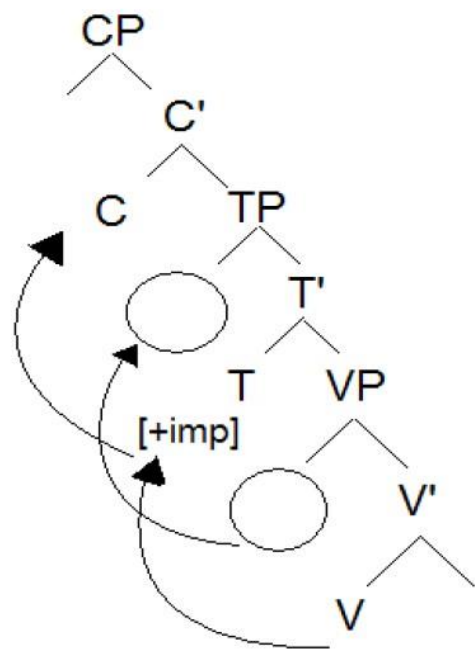

Розглянемо це на прикладі речення: Open the door.

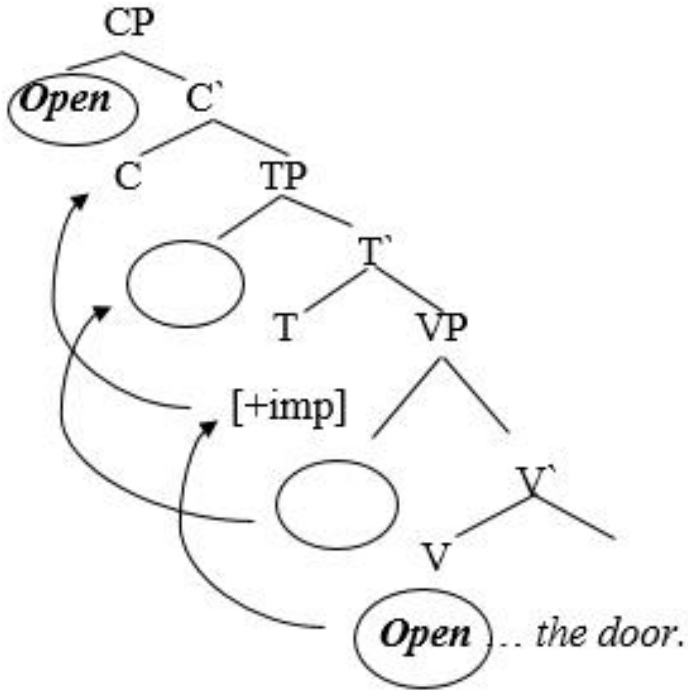


3 ілюстрації помітне чітке переміщення дієслова 3 позиції $V$ на позицію $T$, де функція [+imp] переносить його на позицію $C$, що пояснює таким чином ініціальну позицію дієслова в реченні. Відбувається також пересув із позиції $S p e c$ у VP на позицію $S p e c$ у TP, заповнюючи місце підмета в реченні ${ }^{5}$.

В англійській мові XV-XVII ст. імперативи $€$ панівним типом директивних мовленнєвих актів. Оскільки імперативи входять до складу наказових речень, то варто зазначити, що це був єдиний тип дієслівних речень, які ще 3 давньоанглійського періоду зберегли односкладову структуру. Зміни, які відбуваються у сфері наказових речень, мали переважно морфологічний характер і були пов'язані 3 розвитком наказового способу. Напр.:

(12) Wende with him in his jurné / And com ogain this day! (Amis and Amiloun, 275-276) - «Йди з ним у його мандрівку / Та повертайся назад иъього ж дня!».

Із середньоанглійського періоду відбувається диференціація форм наказового способу за особами. З'являються форми звертання до 3-ої особи однини та множини, а також 1-ої особи множини. Отже,

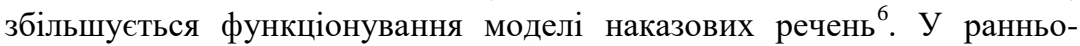
новоанглійський період починається становлення загальної моделі директивної клаузи. Імператив, в основі якого лежить звертання до 2-ої особи, усе ще домінує як вид директивів.

У ранньоновоанглійський період утворення імперативів відбувалось за допомогою безпосередньо самого дієслова або дієслів, як-от соте (cum), go (wende) and let (lat, lete):

(13) "Lat me go, - than sayde the sheriff, / For saynte charité $<\ldots>$ " (A Gest of Robyn Hode; 801) - «Вiдпустіть мене, - сказав шериф, заради всього святого <...>»;

(14) "Give me thy hand <...>" (The Shoemaker's Holiday; p. 12) "Дай мені свою руку <...>».

Розвідка показала, що структура цього типу імперативів була діахронічно стійкою. Наприклад речення (14) матиме структурну схему, яка відповідатиме структурній схемі імперативної клаузи в сучасній англійській мові. Пор.:

${ }^{5}$ Potsdam Eric. Analysing Word Order in the English Imperative. Linguistik Aktuell / Linguistics Today 103. Amsterdam : John Benjamins, 2007. P. 251.

${ }_{6}^{6}$ Иванова И., Чахоян Л. История английского языка. Москва : Высш. шк., 1976. C. 263. 


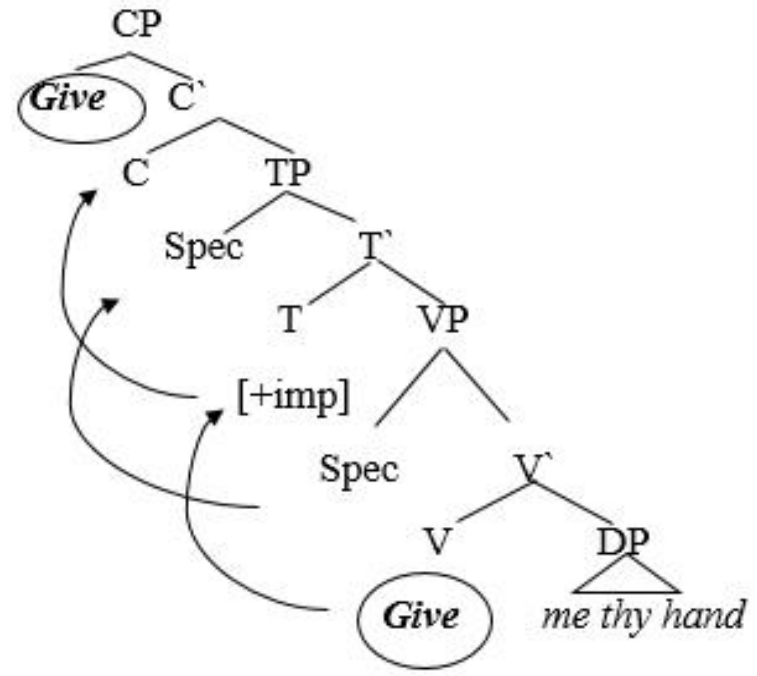

Приклад (14) із ранньоновоанглійського періоду показує ініціальне розташування імперативного дієслова та нульовий підмет, що доводить діахронічну стійкість такого типу імперативного речення. Так, наприклад, речення (12), що належить до літературної пам'ятки середньоанглійського періоду XIII ст., матиме синтаксичну структуру. Пор.:

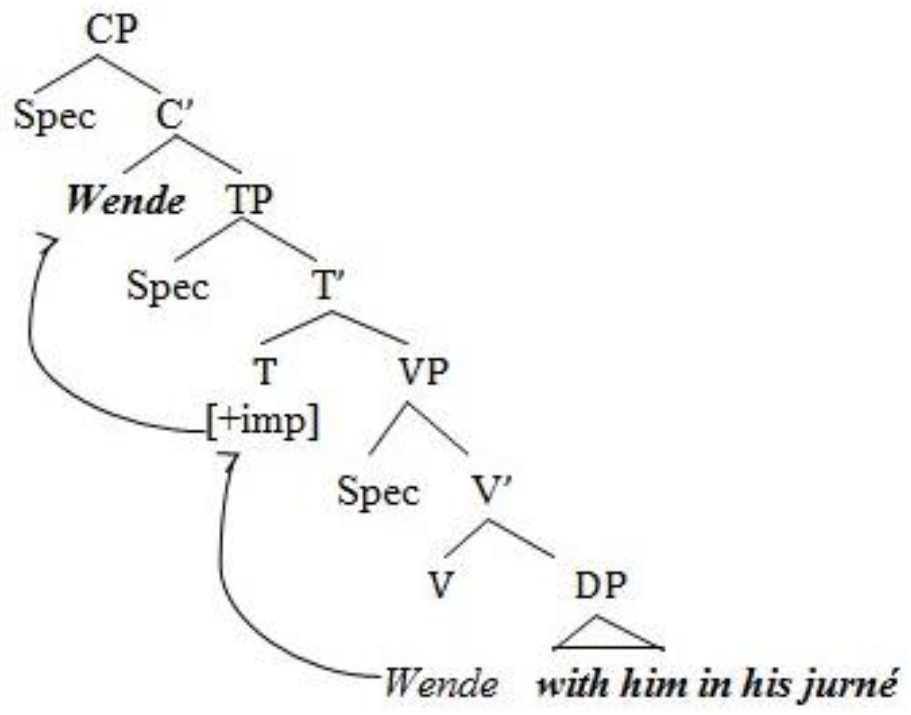


Але в досліджуваний період простежується вживання імперативних речень із наявними підметами, які розташовувались у постпозиції до імперативного дієслова та виражались такими займенниками, як: thou, thee, ye, уои. Напр.:

(15) "Ring ye the bels, ye yong men of the towne <...>" (Epithalamion) - «Дзвоніть у дзвони, молодь иього міста <...>»;

(16) "And the trouth tell thou me" (A Gest of Robyn Hode, 981) «I правду скажи мені».

Схематично зазначений вище тип імперативів можна представити у вигляді такого дериваційного дерева (15):

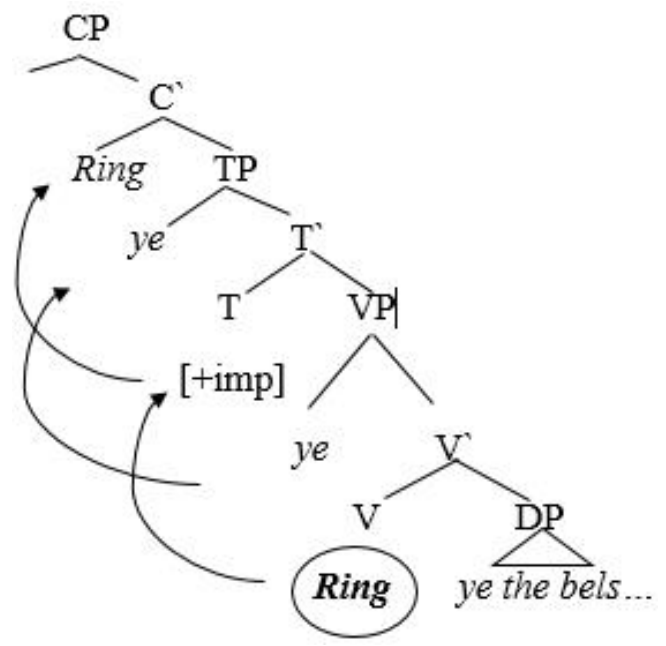

У сучасних лінгвістичних студіях учені все частіше розглядають речення 3 погляду теорії інформаціїної структури (далі - IC), яка спирається на Програму мінімалізму Н. Хомського. IC вивчає внутрішні та зовнішні функуції конституентів речення. Відповідно IC речення відображає його членування на відомий зміст (топік) та нове невідоме (фокус).

Однією 3 найбільш відомих і поширених генеративних моделей $є$ модель лівої периферії Л. Ріцці ${ }^{7}$, згідно з якою компоненти IC речення пов'язані один з одним формулою:

$$
\text { ForceP }>\text { TopP }>\text { FocusP }>\text { TopP }>\text { FinP }>\text { TP }<\ldots>\text {. }
$$

${ }^{7}$ Rizzi Luigi. The Fine Structure of the Left Periphery. Elements of Grammar : Handbook of Generative Syntax / ed. Liliane Haegeman. Dordrecht : Kluwer, 1997. P. 281-337. 
Вона складається із силової фрази (ForceP), яка показує зв'язок речення 3 контекстом; топік (ТорР) відображає стару інформацію в контексті; фокус (FocusP) пояснює нову інформацію; фінітна фраза (FinP) має такі елементи, як час, стан, спосіб тощо. Звідси, топік і фокус $\epsilon$ проміжними елементами між ForceP та FinP. Дериваційна модель інформаційної структури речення буде мати такий вигляд:

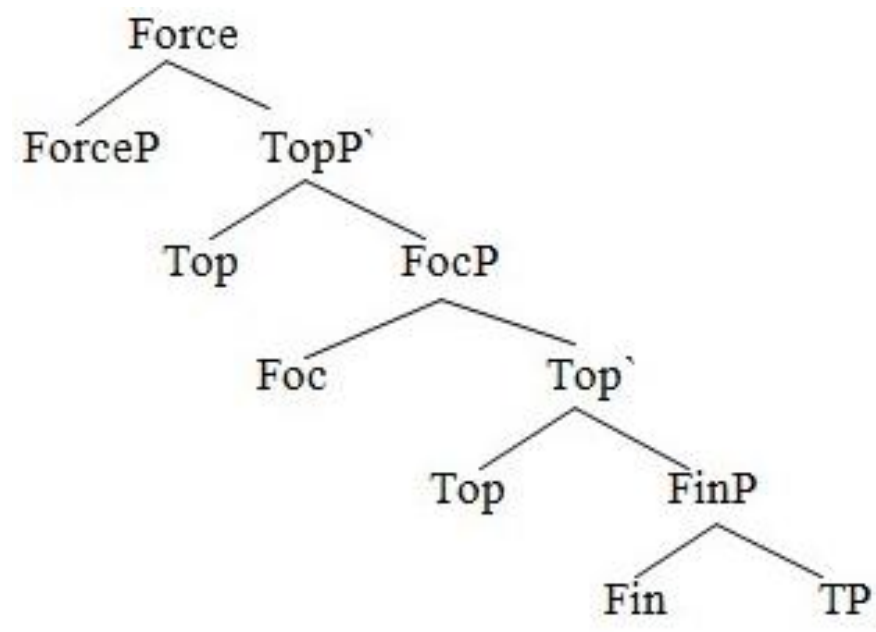

Інформаційна структура імперативів в англійській мові відрізняється від структури декларативів і питань. Ліва периферія має три позиції: комплементайзер (complementizer), фокус та фінітну групу. В імперативних речення вершини (head) немає. Усе це буде представлено трипозиційною моделлю CP: CP > FocusP > FinP > $T P<\ldots>^{8}$.

В англійській мові модель для імперативного комплементайзера має таку особливість: [-Sub, Force $\{$ IMP $\},-$ Top]. Значущість [Top] не $\epsilon$ у вільному варіюванні, оскільки наявність топіка [+Тор] буде вимагати ще одну позицію в моделі СР. Особливості структури лівої периферії в англійській мові не дозволяють переміщення у структурі, тому відповідно $\mathrm{C}^{0}$ не може притягувати DP через відсутність топіка [-Top]. Наявність Focus $^{0}$ залежить від того, чи представлена в реченні фокусна альтернатива (focal alternative).

${ }^{8}$ Rizzi Luigi. The Fine Structure of the Left Periphery. Elements of Grammar : Handbook of Generative Syntax / ed. Liliane Haegeman. Dordrecht : Kluwer, 1997. P. 281. 


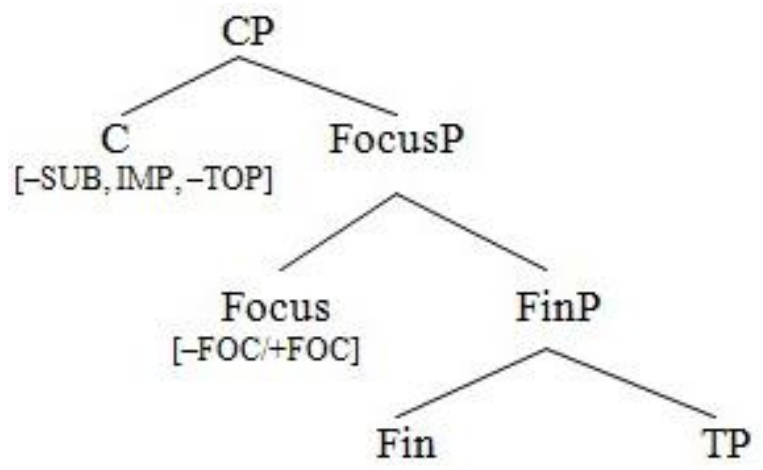

Варто зазначити, що фокусом речення $є$ найбільш наголошена лексична одиниця, яка формує ядро речення. Дериваційна модель інформаційної структури речення (14) виглядатиме так:

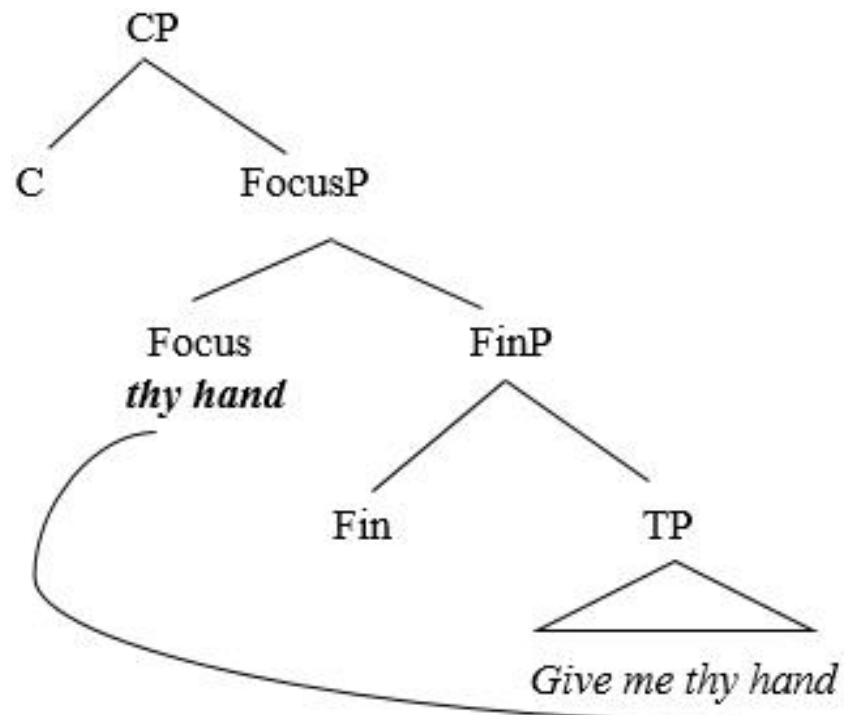

Нуклеарний наголос у реченні падатиме на thy hand, що і буде становити фокус речення. Але, як уже зазначалось вище, в імперативних реченнях може не бути фокус-групи, що робить неможливим визначення фокуса речення. Це може відбуватись як через відсутній нуклеарний наголос, так і через відсутність нової інформації для слухача. Напр.: 
(16) "Come now ye damzels, daughters of delight <..>" (Epithalamion) - «Сюди, дівчата, дочки насолоди <...>».

Складність аналізу в діахронії полягає в тому, що неможливо достеменно проаналізувати інтонації в давніх текстах. Можливість такого аналізу також доводить, що наявність фокуса залежить саме від нуклеарного наголосу. У реченні, представленому у прикладі (16), важко визначити найбільш наголошений елемент. Тому можемо говорити про відсутність наголосу та, відповідно, фокуса. Отже, інформаційна структура речення матиме таку модель:

[CP [FinPCome now ye damzels, daughters of delight]].

Ураховуючи порядок слів у зазначеному вище реченні, ми бачимо розташування всієї клаузи у фінітній групі, пересування з якої за структурою не відбувається. Сучасна англійська мова не допускала б пересуву, отже, інверсії в такій клаузі. Але беручи до уваги період, 3 якого взятий приклад (16), а саме середньоанглійський період XVI ст., ы особливість порядку слів у даний період, який тільки починає бути схожим на той, який $є$ в сучасній англійській мові, можна припустити, що такий рух конституентів був можливий. Напр.:
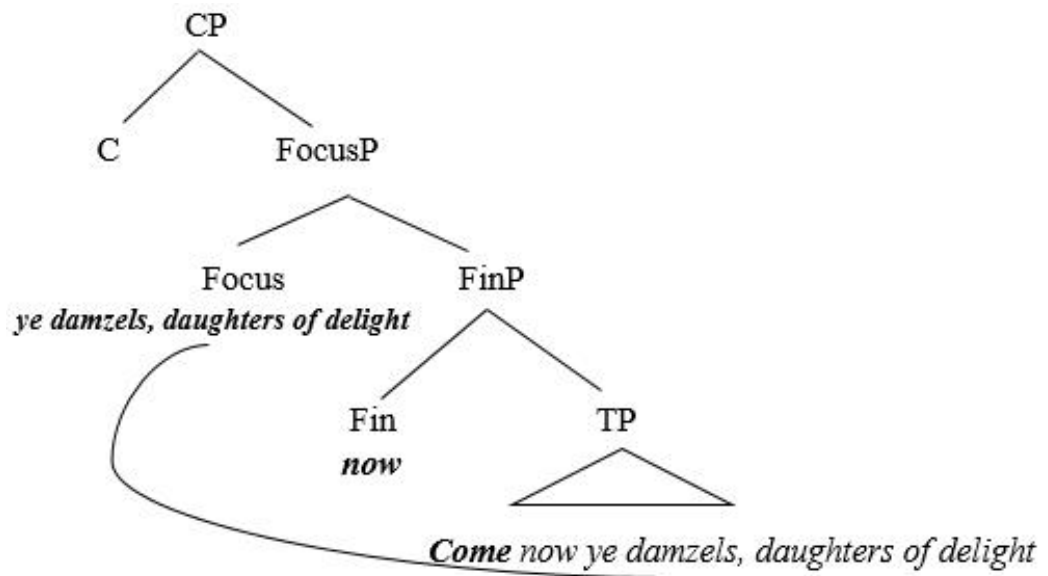

Звідси, наголос, отже, і фокус, залежать також від порядку слів у реченні.

\section{3. Дісслово pray як маркер ввічливості в імперативах}

У сучасній англійській мові за вживання імперативів часто використовується маркер ввічливості please, що надає імперативу менш категоричної тональності. У середньоанглійський період слово please як 
самостійне почало використовуватись лише після XVII ст/, до цього вживались лише довші версії цього маркера ввічливості, на зразок: An please you, I fit please you. Утім більш вживаними маркерами ввічливості в імперативних конструкціях були (Y)pray (preie) thee або praieth.

М. Укаджі досліджував форми I pray уоu, I beseech уои та I command уои в ранньоновоанглійському періоді, особливо у працях В. Шекспіра, аналізуючи їхню імперативну структуру ${ }^{9}$. Базуючись на дослідженні Дж. Росса, М. Укаджі говорить про те, що імперативне значення вищенаведених форм походить із головного дієслова в реченні, (I) pray $\epsilon$ одним із них.

Р. Браун і А. Гілман досліджували способи мовного вираження ввічливості, відносячи I pray уоu, pray уои та prithee до непрямих прохань $^{10}$. Ч. Барбер у своїх працях також досліджує вираження ввічливості за допомогою фраз I prethe та I prey thee ${ }^{11}$.

P. Копитько аналізує п’єси В. Шекспіра, основуючись на позитивних та негативних стратегіях ввічливості П. Браун i С. Левінсон, показуючи розвиток і перехід від панівної позитивної ввічливості до сучасної негативної ввічливості ${ }^{12}$.

Під час дослідження нами було засвідчено, що ця модель була найбільш поширеною протягом досліджуваного періоду та виявилась діахронічно стійкою, про що свідчить наявність їі в текстах, починаючи з XIII ст. У досліджуваних нами пам'ятках писемності початку XII ст. не було зафіксовано вживання МА 3 даним типом маркування. Це можна пояснити появою та розвитком самого слова pray, яке, як уже зазначалось вище, з'явилось на початку XII ст. Однак широкого використання в текстах це слово набуло із XIII ст. До цього ж використовувався тогочасний відповідник - bidde («просити», «благати»). Напр.:

(17) "What have they don? I pray yow, telle me that" (The Assembly of Ladies, 149) - «Що вони зробили? Я прошу тебе, скажи мені»;

Структура I pray уои наявна протягом усього досліджуваного періоду i характеризується високою частотою вживання. Якщо говорити про структуру цього виду МА, то синтаксична дериваційна модель теж мала свої особливості. Стосовно розташування в реченні, то pray та prithee стояли або в ініціальній, або в постпозиції до підмета і

${ }^{9}$ Ukaji M. Imperative Sentences in Early Modern English. Tokyo : Kaitakusha, 1978.

10 Brown R., Gilman A. Polite theory and Shakespeare's four major tragedies. Language in Society. 1989. № 18. P. 159-212. P. 34.

1997.

12 Kopytko R. Linguistic politeness strategies in Shakespeare's plays. Historical Pragmatics / A. Jucker (ed.). Amsterdam : John Benjamins, 1995. P. 532. 
присудка: Pray + the/ you / thee / yow. Тобто розташування маркера могло варіюватись:

I pray you / thee + Verb $+[\mathrm{Obj}])$

(Verb + Subj / Obj + I pray you / thee $)$.

Отже, дериваційна модель цього типу МА мала таку структуру:

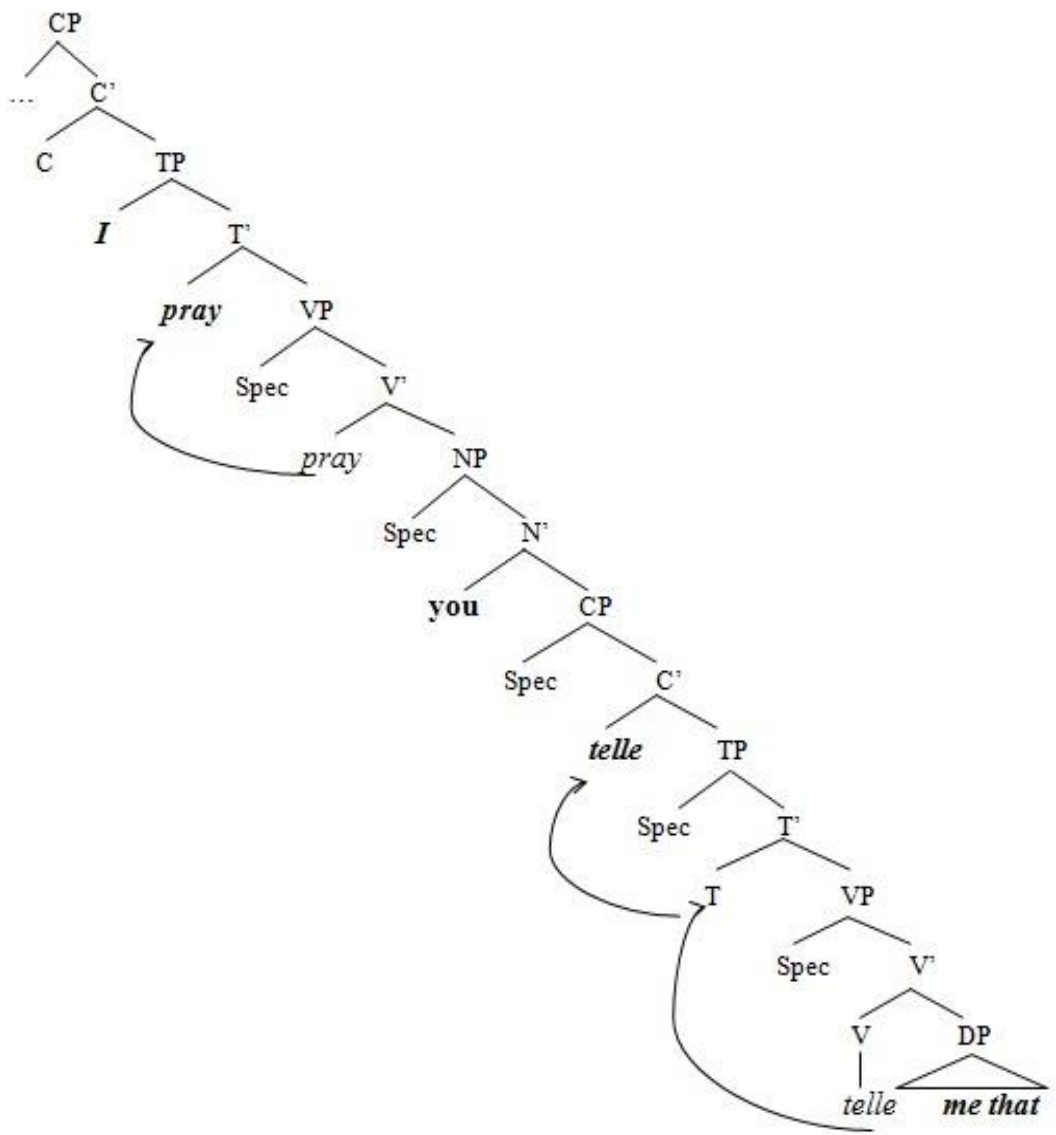

Синтаксична структура самого речення, a саме позиційне розташування конституентів у дериваційній моделі, змінювалась відповідно до зміни розташування самого маркера. Зазначимо, що речення зазвичай складалось 3 імпертивної клаузи, структура якої, як ми вже зазначали раніше, зазнавала переміщення V-to-T-to-C, a позиційне розташування конституентів було аналогічним до їхньої позиції в імперативному реченні. 


\section{ВИСНОВКИ}

Матеріал дослідження імперативів дозволяє зробити висновок про наявність їхніх специфічних властивостей, які відрізняють імперативні клаузи від інших типів директивів. Діахронічне дослідження ранньоновоанглійського періоду дозволило виділити структурні особливості, зокрема розташування імперативного дієслова та підмета. У досліджуваний період нами простежується вживання імперативних клауз із наявними підметами, які розташовувались у постпозиції до імперативного дієслова. Такий тип наказових речень виявився діахронічно стійким і зберігся до XV ст. із часів давньоанглійського періоду. Виникають форми звертання до 3-ої особи однини та множини, а також 1-ої особи множини. Відповідно, починає збільшуватись використання моделі наказових речень. У ранньоновоанглійський період проходить становлення загальної моделі директивної клаузи. Імператив, зі звертанням до 2-ої особи, на досліджуваний період залишається панівним видом директивів.

Наша розвідка дозволила нам виділити основні маркери імперативів в історії англійської мови, способи їх утворення. Отже, нами було виділено найбільш уживані маркери, як-от сит (come), wende (go), lat, lete (let) and pray. Однак імперативи утворювались і за допомогою інших дієслів.

Синтаксична модель структури імперативної клаузи з ініціальним розташуванням дієслова та нульовим підметом у досліджуваний період $\epsilon$ аналогічною моделі в сучасній англійській мові. Це дозволяє нам зробити висновок, що становлення сучасної структури імперативних речень відбулось із кінця середньоанглійського та початку ранньоновоанглійського періодів.

\section{АНОТАЦІЯ}

У статті досліджено структурні особливості імперативів у пам'ятках літератури середньоанглійського та ранньоновоанглійського періодів. Наша розвідка дозволяє проаналізувати функціонування та маркування імперативу в діахронії та зробити компаративний аналіз із сучасним етапом.

В історії англійської мови імперативи $є$ найбільш уживаним типом директивних мовленнєвих актів. Імперативи $є$ невід'ємною частиною наказових речень, які виявилися діахронічно стійкими та зберегли односкладову структуру ще 3 давньоанглійського періоду. Зміни, які відбулися з наказовими реченнями, мали переважно морфологічний $\mathrm{i}$ прагматичний характер i були пов'язані 3 розвитком наказового способу та мовою загалом. 
Диференціація форм наказового способу за особами в історії англійської мови відбувається з XV ст. Виникають форми звертання до 3-ої особи однини та множини, а також 1-ої особи множини. Відповідно, починає збільшуватись використання моделі наказових речень. У ранньоновоанглійський період проходить становлення загальної моделі директивної клаузи. Імператив, зі звертанням до 2-ої особи, на досліджуваний період залишається домінуючим видом директивів.

Наша розвідка дозволила нам виділити основні маркери імперативів в історії англійської мови, способи їх утворення. Отже, нами було виділено найбільш уживані маркери, як-от pray, cum (come), wende (go) and lat, lete (let). Однак імперативи утворювались і за допомогою інших дієслів.

Ураховуючи сучасні підходи до аналізу синтаксичної струкури речення, нами було визначено особливості розташування імперативного дієслова та підмета в досліджуваний період. Також завдяки здобуткам лінгвістичних розвідок генеративної моделі інформаційної структури речення ми змогли встановити залежність наголосу і фокусу речення від порядку слів у діахронічному аспекті.

\section{ЛITЕРАТУРА}

1. Иванова И., Чахоян Л. История английского языка. Москва : Высш. шк., 1976. 319 с.

2. Aijmer Karin. Conversational Routines in English: convention and creativity. Harlow : Longman, 1996. As cited in : Culpeper, Jonathan and Dawn Archer. Requests and directness in Early Modern English trial proceedings and play texts. Speech Acts in the History of English / Jucker, Andreas H. and Irma Taavitsanien (eds.). Amsterdam / Philadelphia : John Benjamins, 2008.

3. Alcazar A., Saltarelli M. The syntax of imperatives. Cambridge : Cambridge University Press, 2014.

4. Austin John L. How to Do Things with Words. Oxford : Oxford University Press, 1962.

5. Barber C. Early Modern English. Edinburgh : Edinburgh University Press, 1997.

6. Brown P., Levinson S. Politeness: Some Universals in Language Usage. Cambridge : Cambridge University Press, 1987.

7. Brown R., Gilman A. Polite theory and Shakespeare's four major tragedies. Language in Society. 1989. № 18. P. 159-212.

8. Busse Ulrich. Changing politeness strategies in English requests : A diachronic investigation. Studies in English Historical Linguistics and 
Philology : A Festschrift for Akio Oizumi / Jacek Fisiak (ed.). Frankfurt am Main : Peter Lang, 2002. P. 17-35.

9. Culpeper Jonathan, Dawn Archer. Requests and directness in Early Modern English trial proceedings and play texts. Speech Acts in the History of English / Jucker, Andreas H. and Irma Taavitsanien (eds.). Amsterdam / Philadelphia : John Benjamins, 2008.

10. Fawcett R. A theory of syntax for systemic functional linguistics. Amsterdam / Philadelphia : John Benjamins, 2000.

11. Halliday M. Halliday's introduction to functional grammar. $4^{\text {th }}$ ed. London and New York : Routledge, 2014.

12. Hopper Paul J., Traugott Closs Elizabeth. Reprint. Grammaticalization. (Cambridge Textbooks in Linguistics). Cambridg e: Cambridge University Press ; Original edition 1993, 2003. P. 10-14.

13. Huddleston R., Pullum G. The Cambridge grammar of the English language. Cambridge : Cambridge University Press, 2002.

14. Jespersen O. Essentials of English grammar. 1933. London : Routledge, 2002.

15. Kohnen Thomas. Let mee bee so bold to request you to tell me": Constructions with "let me" in the history of English directives. Journal of Historical Pragmatics. 2004. № 5:1. P. 159-173.

16. Kohnen Thomas. Text types and methodology of diachronic speech act analysis. Methods in Historical Pragmatics / Irma Taavitsainen, SusanFitzmaurice (eds.). Berlin ; New York : Mouton de Gruyter, 2007. P. 139-166.

17. Kopytko R. Linguistic politeness strategies in Shakespeare's plays. Historical Pragmatics / A. Jucker (ed.). Amsterdam : John Benjamins, 1995. P. 515-540.

18. Krug Manfred. Modality and the History of English Adhortatives. Modality in English. Theory and Description (Topics in English Linguistics) / Raphael Salkie, Pierre Busuttil \& Johan van der Auwera (eds.). Berlin and New York : Mouton de Gruyter, 2009.

19. Ogura Michiko. "Gewat + Infinitive" and "Uton + Infinitive". Neuphilologische Mitteilungen 101. 2000. P. 69-78.

20. Potsdam Eric. Analysing Word Order in the English Imperative. Linguistik Aktuell / Linguistics Today 103. Amsterdam : John Benjamins, 2007. 251-272 p.

21. Pullum Geoffrey K., Huddleston Rodney. Negation. The Cambridge Grammar of the English Language / Rodney Huddleston, Geoffrey K. Pullum (eds.). 2002.

22. A comprehensive grammar of the English language / R. Quirk et al. London : Longman, 1985. 
23. Rizzi Luigi. The Fine Structure of the Left Periphery. Elements of Grammar: Handbook of Generative Syntax / ed. Liliane Haegeman. Dordrecht : Kluwer, 1997. P. 281-337.

24. Ross J. On declarative sentences. Readings in English Transformational Grammar / J. Roderick, P. Rosenbaum (eds.). Waltham, Mass. : Ginn and Company, 1970. P. 222-272.

25. Rupp Laura. Inverted' Imperatives. Imperative Clauses in Generative Grammar: Studies in Honour of Frits Beukema / ed. Wim van der Wurff. Linguistik Aktuell / Linguistics Today 103. Amsterdam : John Benjamins, 2007.

26. Taavitsainen Irma, Jucker Andreas H. Speech acts verbs and speech acts in the history of English. Methods in Historical Pragmatics / Irma Taavitsainen, Susan Fitzmaurice (eds.). Berlin ; New York : Mouton de Gruyter, 2007. P. 107-138.

27. Ukaji M. Imperative Sentences in Early Modern English. Tokyo : Kaitakusha, 1978.

\section{Information about the author:} Zizinska A. P., Lecturer at the Department of Roman and Germanic Philology and Translation

Bila Tserkva National Agrarian University 8/1, Soborna sq., Bila Tserkva, Kyiv region, 09117, Ukraine 